\title{
Evaluation of Shear Strength and Cyclic Delamination of Paricá (Schizolobium amazonicum) Glued Laminated Timber
}

\author{
Raquel Schmitt Cavalheiro ${ }^{1}$, Carlito Calil Neto², André Luis Christoforo ${ }^{3, *}$, \\ Carlito Calil Junior ${ }^{4}$, Francisco Antonio Rocco Lahr ${ }^{4}$
}

\author{
${ }^{1}$ Department of Materials (SMM), São Paulo University (EESC/USP), São Carlos, Brazil \\ ${ }^{2}$ Wood and Timber Structures Laboratory (LaMEM), São Carlos Engineering School, São Paulo University - USP, São Carlos, Brazil \\ ${ }^{3}$ Centre for Innovation and Technology in Composites - CITeC, Department of Civil Engineering (DECiv), Federal University of São \\ Carlos, São Carlos, Brazil \\ ${ }^{4}$ Department of Structural Engineering (SET), São Paulo University (EESC/USP), São Carlos, Brazil
}

\begin{abstract}
Glued laminated timber (glulam) is an engineered product that requires manufacturing precision in all its stages. The finished product can only be tested in laboratory conditions; however, it is necessary to provide the quality control in production to ensure that glulam properties are appropriate to the product specified requirements in accordance with proper codes. This research aimed to evaluate the proposed trials conducted with combinations of Paricá (Schizolobium amazonicum, a tropical wood species coming from a certificate reforestation area), three adhesives (polyurethane, phenol resorcinol formaldehyde, melamine formaldehyde) and two types of treatment (CCA, CCB). The shear strength and delamination test results of all the treated samples showed the good performance of Paricá glulam, which can be used to indoor and outdoor applications.
\end{abstract}

Keywords Glued laminated timber, Treatment, Structural adhesives, Reforestation species

\section{Introduction}

As discussed in previous reports it is important investigating wood from different species as alternatives in preparing Glued Laminated Timber [1]. As an engineered wood product Glued Laminated Timber (Glulam) requires manufacturing precision in all its stages [2-4], and only laboratory tests can be used to evaluate finished specimens [5-7]. To ensure that glulam properties are appropriate to the strength required by normative codes quality control is required in production [8]. In this research, shear strength (failure mode in glue line) and delamination data are presented. These tests were performed at LaMEM (Wood and Timber Structures Laboratory), Structural Engineering Department, São Carlos Engineering School, São Paulo University, in Brazil, in order to evaluate some combinations of adhesive-treatment according to standardized specifications [9]. Paricá (Schizolobium amazonicum, a tropical wood species coming from a certificate reforestation area), three treatments conditions (CCA, CCB and no

* Corresponding author:

christoforoal@yahoo.com.br (André Luis Christoforo)

Published online at http://journal.sapub.org/ijme

Copyright $(2016$ Scientific \& Academic Publishing. All Rights Reserved treatment, as reference) and three adhesives (polyurethane HB S309, phenol resorcinol formaldehyde RS 216M and Melamine MUF 1242/2542) were adopted.

In 1948, through the Forest Service of the State of São Paulo, American species known as "yellow pine", which include Pinus palustris, P. echinata, P. elliottii and P. taeda, were introduced for testing. Among these, the last two stand out for ease in cultivation, rapid growth and intense reproduction in the South and Southeast of Brazil. Since then, a large number of species continued to be introduced and established in field experiments by government agencies and private companies seeking to establish commercial plantations.

Shizolobium amazonicum (Paricá), because of rapid growth, bole straight and wood with high price in domestic and foreign markets, has been extensively cultivated by logging companies in the northern and northeastern regions of Brazil, mainly in the states of Pará and Maranhão. According to Paricá Research Center (CPP), in municipality of Dom Eliseu, southern Pará, which represents the vast majority of Paricá planters in the states of Pará and Maranhão, it is estimated that in these states there is around 40,000 hectares of the planted species.

Paricá is endemic vegetable specie in Brazilian Amazon, as well as in Venezuelan, Colombian, Peruvian and Bolivian. 
In Brazil, it is found in states of Amazonas, Pará, Mato Grosso and Rondônia, in clay soils of primary and secondary forests, both on land and in high floodplain.

Paricá trees can reach 15 to 40 meters high and 50 to $100 \mathrm{~cm}$ stem diameter, presenting a cylindrical and straight trunk. In young trees the bark, is greenish and thin, becoming later gray, thick, hard, and rough and with vertical strips of lenticels; musk has unpleasant odor.

The wood is soft, light, with thick texture, grain straight to irregular, reddish cream heartwood and sapwood cream-clear. It offers easy processing and receives good finish, but has low natural durability, being susceptible to fungi, termites and wood-destroying insects. It is used in the manufacture of matches, toys, models, light packaging, canoes, liners, core panels and doors, concrete forms, veneer, plywood, pulp and paper.

The tree is suitable for commercial plantations, agroforestry and reforestation of degraded areas due to its rapid growth and good performance both in homogeneous formations as in consortia. Figure 1 shows the image of Paricá wood specie.

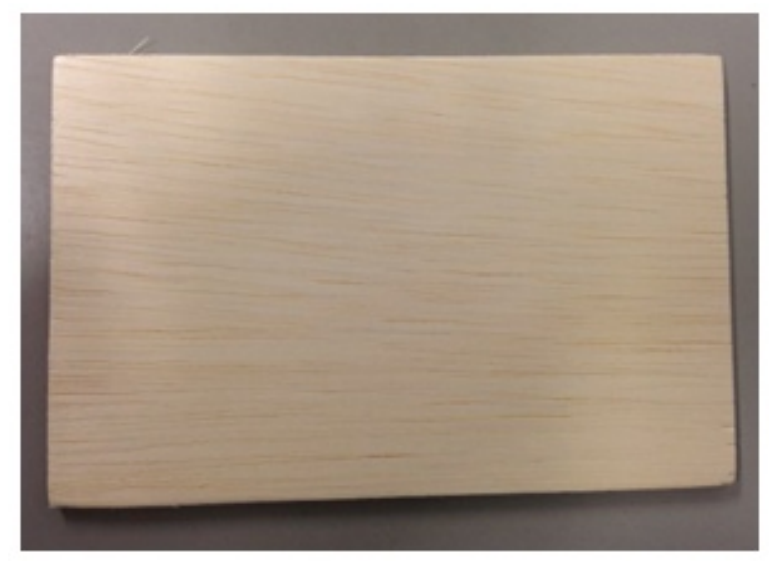

Figure 1. Paricá wood specie

Wood properties have a deep effect on adhesive performance. Hardwood is generally more difficult in gluing than the softwood. Wood anatomical properties have a significant influence on wood bonding, such as the variability in density and porosity, heartwood and sapwood, and juvenile wood and mature wood. Furthermore, there exists the influence of the dimensional instability of reaction wood, as well as the direction of the grain, in which the penetration relates to the cutting direction.

Each kind of tree has its own growth pattern. During growing season, different cell types and sizes are formed. The adhesive should be chosen considering: weather conditions of use (use classes), wood species, preservative and manufacturing methods. The use classes of structural laminated elements are shown in Table 1 [9].

Wood preservation consists of its impregnation with toxic substances, so that they can no longer be used as food for termites or fungi.

Preservative treatment of glued laminated timber must be performed after its manufacturing, checking the compatibility between adhesive and treatment to be used [10]. When the dimensions become thinner, Glulam treatment is impossible, preserved wood should be used for their manufacture. In all cases, the wood moisture content must be controlled, and the compatibility of preservative with adhesive should be checked. So, recommendations of the manufacturers of preservatives and adhesives should be followed for their compatibility.

\section{Material and Methods}

Paricá wood specimen was classified by visual and mechanical evaluation before using in glulam assembling. With the help of classification rules reference, the growth characteristics are used to select the timber classes of visual quality. Visual grading of Paricá wood was performed according to the criteria adopted from the Brazilian standard [11].. The average wood moisture content was $12 \%$. Gluing was performed with layers of wood without treatment using the two types of adhesives. Bonding was made no longer than 24 hours after planning.

Besides, 180 to $200 \mathrm{~g} / \mathrm{m}^{2}$ adhesive were applied to one surface, and the assemblies pressed at $1 \mathrm{MPa}$ for 6 hours, according to manufacturer specifications. After assembly, wood pieces were sent to a commercial treatment facility and treated with the preservatives $\mathrm{CCA}$ [chrome $\mathrm{CrO}_{3}(47,5 \%$ ), copper $\mathrm{CuO},(18.5 \%)$ and arsenic $\left.\mathrm{As}_{2} \mathrm{O}_{5}(34.0 \%)\right], \mathrm{CCB}$ $\left[\mathrm{CuSO}_{4}(35.8 \%), \mathrm{H}_{3} \mathrm{BO}_{3}(22.4 \%), \mathrm{K}_{2} \mathrm{CrO}_{7}(38.5 \%)\right.$ and $\mathrm{NaHSO}_{4}(2.1 \%)$ ] and CCBS [the CCB-treated wood - Salt Base]. Chemical treatment was carried out in an autoclave after seven days of adhesive curing, and conditioned to a relative humidity of $12 \%$ after preservative treatment.

The shear test followed American standard specifications [12]. Those with $12 \%$ humidity were considered the dry specimens while the wet ones were obtained after keeping them under water during 48 hours.

Table 1. Classification for structural use according to moisture of the wood and temperature of application [9]

\begin{tabular}{ccccc}
\hline Use Classes & Description & Moisture of the wood & Temperature & Type of Adhesive* \\
\hline 1 & Interior & $\leq 12 \%$ & $<50^{\circ} \mathrm{C}$ & I \\
2 & Exterior & $\leq 18 \%$ for wood without treatment & & \\
3 & Covered & $\leq 20 \%$ for softwoods with treatment & $<50^{\circ} \mathrm{C}$ & I \\
\hline
\end{tabular}

* I - adhesives for interior use; II - adhesives for interior and exterior use 
The delamination tests followed the Canadian standard [13] except that the glued assembly nominal dimensions were $210 \mathrm{~cm}$ long, $10 \mathrm{~cm}$ wide and $4 \mathrm{~cm}$ thick. Figure 2 shows a specimen used to determine the shear strength.

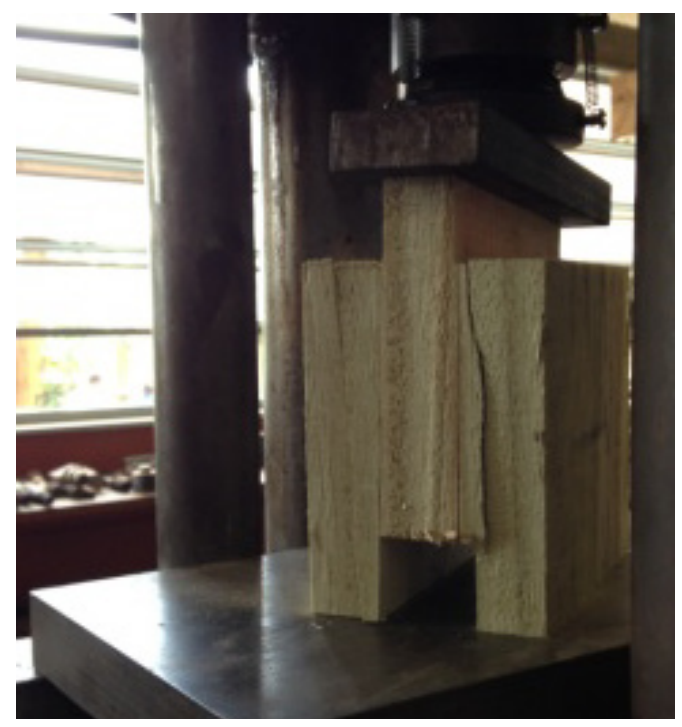

Figure 2. Specimen used to determine the shear strength

The criteria to be considered for the "use classes" for acceptance of combinations of adhesive-preservative treatment was as follows:

- the delamination test on the Canadian standard [13] describes that the delamination of all glued lines of the specimen should not exceed $1 \%$;

- the shear test, the coefficient of variation is $28 \%$, similar to that prescribed by the Brazilian Standard [11].

Failure mode must be considered for:

- specimens with a total break in the adhesive line tested in the dry condition were considered substandard;

- specimens with a total break in the line of adhesive in a wet condition were classified as a class for "internal use".

To investigate the influence of the factors: type of adhesive, type of preservative treatment and moisture content, in the shear strength, was used to the analysis of variance (ANOVA), considered the significance level of 5\%. The null hypothesis formulated consisted in the equivalence of means between treatments, and the non-equivalence as an alternative hypothesis. Thus, P-value less than 0.05 implys rejecting the null hypothesis, accepting it otherwise. The Anderson-Darling and Bartlett tests were used to verify the normality of the residuals of the ANOVA and equivalence of variances between treatments. For the formulation of the tests, the P-value superior than 5\% involves accepting that the distribution of residuals is normal and the variances between treatments are equivalent, which validates the ANOVA models.

A total of 216 specimens have been analyzed in the shear test. being 24 specimens without treatment, ( 8 were glued with polyurethane, 8 with phenol resorcinol formaldehyde, 8 with melamine formaldehyde) and 96 treated with CCA and 96 with $\mathrm{CCB}$ (being 32 of each treatment glued with polyurethane, 32 with phenol resorcinol formaldehyde, 32 with melamine formaldehyde), half of these samples were analysed dry and the other half saturated.

A total of 108 specimens - with the same combination of adhesives and treatments as for the shear test - were essayed in the cycle delamination test [14].

\section{Results and Discussion}

\section{Shear Test}

The specimens subjected to shear assay presented four general behaviors (Fig. 3):

- Compression (wood weaker than the glue line), not considered;

- Shear in the glue line as well as in the wood;

- Shear $100 \%$ at the glue line;

- Shear $100 \%$ at the wood.

During the visual analysis of the results these four behaviors were used to classify the events occurred during the assays. The highest scores referred to compression as presented in Table 2 for each adhesive phenol resorcinol formaldehyde (PRF), melamine formaldehyde (MF) and polyurethane (PU), as well as for the dry and saturated specimens.

The scores in compression observed in all cases suggest that the high porosity of the wood allowed compression instead of break of the specimen.

Concerning the adhesives, it is possible to conclude that MF and PU presented the highest score of $100 \%$ wood rupture, suggesting that such adhesives presented higher adhesion, regardless dry or saturated specimens.

Table 2. Frequency of events observed in the shear test according to visual observation

\begin{tabular}{ccccccc}
\hline \multirow{2}{*}{ Events } & \multicolumn{2}{c}{ PRF } & \multicolumn{2}{c}{ MF } & \multicolumn{2}{c}{ PU } \\
\cline { 2 - 7 } & Dry & Saturated & Dry & Saturated & Dry & Saturated \\
\hline Compression (\%) & 55.6 & 72.2 & 64 & 61.0 & 55.5 & 53.0 \\
$100 \%$ wood (\%) & 8.3 & - & 30.4 & 30.4 & 25.0 & 33.0 \\
$100 \%$ glue line (\%) & 5.5 & 8.3 & - & - & 5.5 & 5.5 \\
Other $^{(*)}(\%)$ & 30.6 & 19.3 & 5.6 & 8.4 & 14.0 & 8.5 \\
\hline
\end{tabular}

(*) - shear in the glue line and/or in the wood. 
The rupture value, $f_{v 0}$, from the shear assays were measured and the average values calculated for the statistical evaluations of the results, as presented in Table 3 for dry and saturated specimens with each adhesive.

Table 3. Mean, coefficient of variation and standard deviations for $f_{v 0}$ values for dry and saturated specimens glued with PRF, MF and PU adhesives

\begin{tabular}{ccccc}
\hline \multirow{2}{*}{$\begin{array}{c}\text { Specimen } \\
\text { Condition }\end{array}$} & Stat. & \multicolumn{4}{c}{ fdhesive } \\
& & PRF & MF & PU \\
\hline \multirow{2}{*}{ Dry } & Mean & 3.4 & 3.7 & 3.5 \\
& CV (\%) & 23 & 24 & $28 \%$ \\
& SD & 0.78 & 0.88 & 0.96 \\
\hline \multirow{2}{*}{ Saturated } & Mean & 2.3 & 2.9 & 2.9 \\
& CV (\%) & 23 & 10 & $19 \%$ \\
& SD & 0.53 & 0.29 & 0.55 \\
\hline
\end{tabular}

CV- coeficient of variation; SD - standard deviation.

The rupture force for the different adhesives was determined considering the values for the specimens, in which only rupture occurred, disregarding those in which compression took place. Figure 3 presents the average rupture force in relation to each adhesive and specimen condition.

From this figure is possible to observe that better results are obtained with dry specimens being the $f_{v 0}$ values lower for saturated samples.

Table 3 presents a summary of the statistical evaluation, performed with the t-Student test for values in Figure 3 considering the averages and standard deviations.

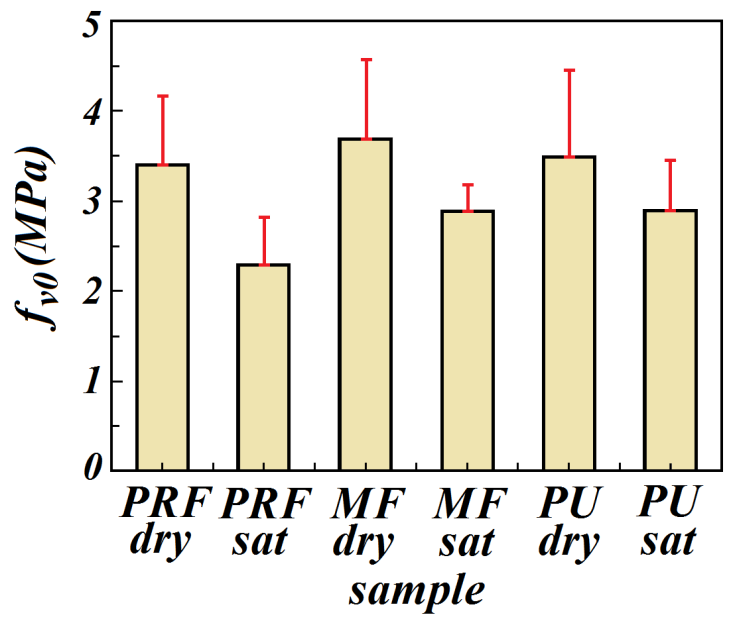

Figure 3. Mean values for the rupture force, $f_{v 0}$, for each adhesive MRF, MF and PU for dry or saturated (sat) specimen

Comparing the $f_{v 0}$ values for the samples glued with the same adhesive, but under different conditions (dry or saturated) it is noticed that the results are statistically different. Thus for PRF-dry $(3,4 \pm 0,8 \mathrm{MPa})>$ PRF-saturated $(2,3 \pm 0,5 \mathrm{MPa})$, as well as for MF-dry $(3,7 \pm$ $0,9 \mathrm{MPa})>\mathrm{MF}$-saturated $(2,9 \pm 0,3 \mathrm{MPa})$ and for PU-dry $\left(3,5 \pm 0,9_{6} \mathrm{MPa}\right)>$ PU-saturated $(2,9 \pm 0,5 \mathrm{MPa})$.

Watching the values of $\mathrm{f}_{\mathrm{v} 0}$ for dry specimens glued with the different adhesives one have:

$M F(3,7 \pm 0,9 \mathrm{MPa}) \cong P U\left(3,5 \pm 0,9_{6} \mathrm{MPa}\right) \cong P R F(3,4 \pm$ $0,8 \mathrm{MPa}$ ), resulting in statistically similar results for the three adhesives according to the data in Table 3.

However considering the saturated specimens glued with the different adhesives one have the order:

$M F(2,9 \pm 0,3 \mathrm{MPa}) \cong P U(2,9 \pm 0,5 \mathrm{MPa})>P R F(2,3 \pm$ $0,5 \mathrm{MPa})$, in which there is significantly statistical difference meaning that the performance of MF and PU are similar, but with $f_{v 0}$ values higher than that observed for PRF, suggesting advantageous application in external usage in favor of the two firsts.

Table 4. Statistical evaluation of the $f_{v}$ values for samples glued with the same adhesive under different specimen condition and paired in two adhesives for dry and saturated specimens

\begin{tabular}{ccccc}
\hline Adhesive $^{\mathbf{a}}$ & $\begin{array}{c}\text { Compared }^{\mathbf{b}} \\
\text { systems }^{\mathbf{b}}\end{array}$ & $\begin{array}{c}\text { Degrees of } \\
\text { freedom }\end{array}$ & $\mathbf{t}_{\text {calc }}$ & $\mathbf{t}_{\text {tab }}$ \\
\hline $\mathrm{PRF}$ & Dry/Sat & 26 & 4.278 & 2.056 \\
$\mathrm{MF}$ & Dry/Sat & 15 & 3.124 & 2.145 \\
$\mathrm{PU}$ & Dry/Sat & 25 & 2.185 & 2.060 \\
\hline $\mathrm{PRF} / \mathrm{MF}$ & Dry & 26 & 0.960 & 2.056 \\
$\mathrm{PRF} / \mathrm{PU}$ & Dry & 31 & 0.323 & 2.040 \\
$\mathrm{MF} / \mathrm{PU}$ & Dry & 29 & 0.584 & 2.045 \\
\hline $\mathrm{PRF} / \mathrm{MF}$ & Sat & 14 & 3.249 & 2.131 \\
$\mathrm{PRF} / \mathrm{PU}$ & Sat & 22 & 2.801 & 2.074 \\
$\mathrm{MF} / \mathrm{PU}$ & Sat & 26 & 0 & 2.056 \\
\hline
\end{tabular}

${ }^{a}$ PRF - phenol resorcinol formaldehyde; MF - melamine formaldehyde; PU polyurethane; ${ }^{\mathrm{b}}$ sat - saturated.

\section{Cyclic Delamination Tests}

This experiment aimed to verifying the displacement under test conditions defined by CSA 0112.9:2004. Figure 4 depicts a general view of the specimens before and after tests, with details of specimens prepared with the three adhesives after delamination cycles.

As can be observed, none of the samples delaminated in glue line, remaining all of them glued and practically intact, suggesting that adhesives as well as chemical treatments are suitable for glulam preparation using Paricá timber layers.

\section{Conclusions}

The proposed methodologies submitted for testing were satisfactory for the classification of combinations adhesive-specie-preservative treatment.

The types of adhesive and wood treatment did not affect significantly the shear strength values, but higher moisture content decreased the $\mathrm{f}_{\mathrm{v} 0}$.

Efficiency of the tested adhesives was evidenced by the failure (observed in shear test) in the wood and not in the glue line, even to the wood in the saturated condition. 


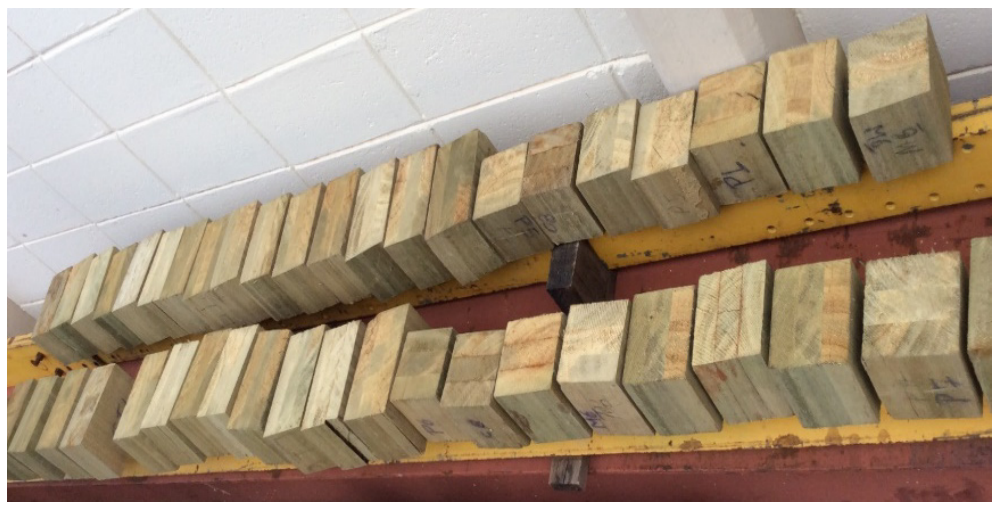

(a)

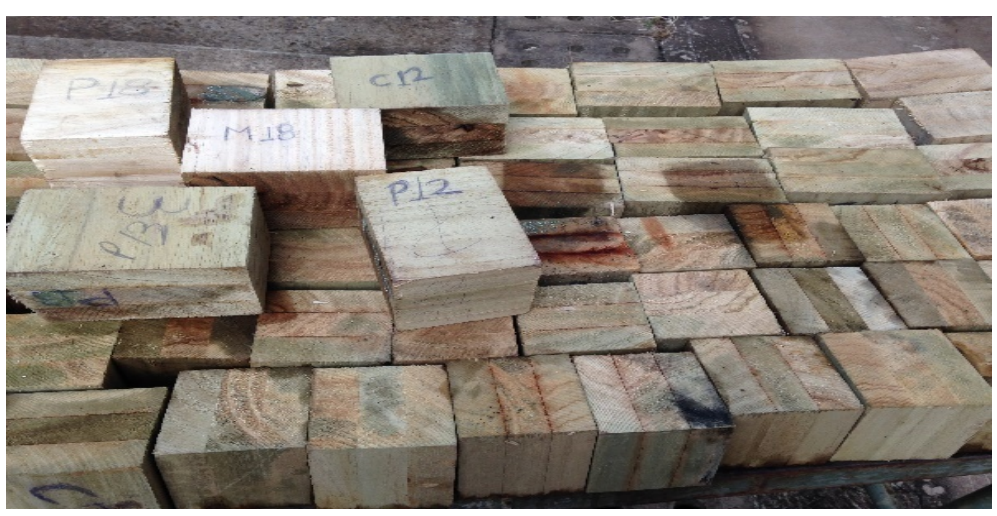

(b)

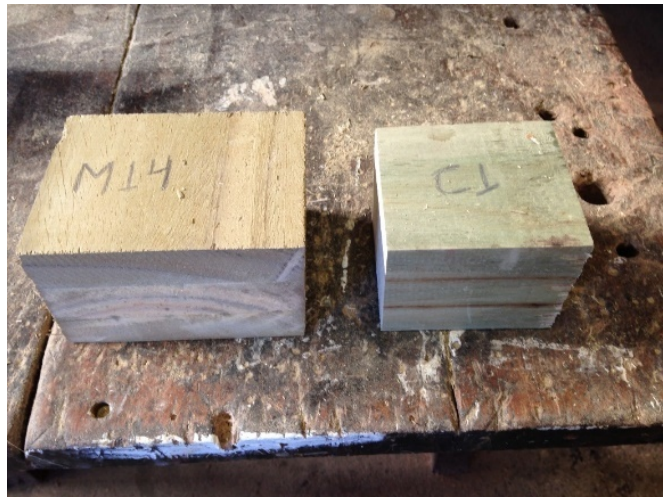

(c)

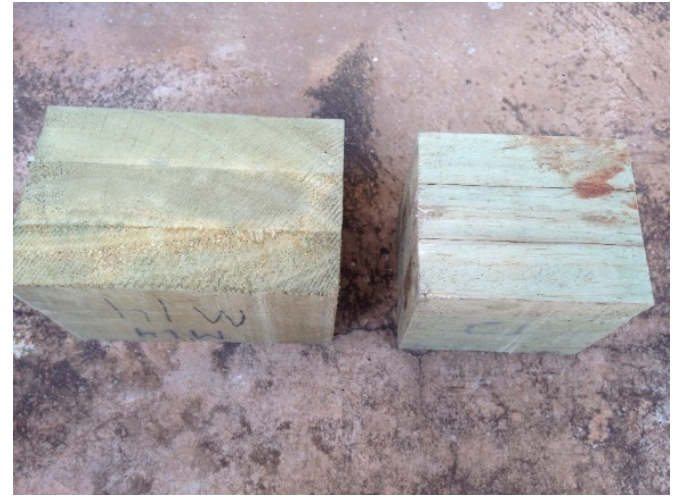

(d)

Figure 4. Specimens used in cyclic delamination test before (a) and after (b) delamination cycle. Details of the specimens melamine formaldehyde (M14) and phenol resorcinol formaldehyde before (c) and after (d) cyclic delamination test

[3] H. Almeida, R. S. Cavalheiro, L. B. Macedo, C. Calil Neto, A. L. Christoforo, C. Calil Jr, F. A. Rocco Lahr. Evaluation of Quality in the Adhesion of Glued Laminated Timber (Glulam) of Paricá and Lyptus Wood Species. International Journal of Materials Engineering, v. 4, p. 114-118, 2014.

\section{REFERENCES}

[1] Miotto, J. L.; Dias, A. A. Glulam-concrete composites: experimental investigation into the connection system. Materials Research, vol.14, no.1, p.53-59, 2011.

[2] Calil, N.; Christoforo, A. L.; Lahr F. A. R.; Calil Jr., C.Analysis of specie treatment - adhesive combinations for glulam purpose. International Journal of Materials Engineering, v. 4, p. 41-47, 2014.

[4] C. Calil Neto, A. L. Christoforo, M. S. Bertolini, F. A. Rocco Lahr, C. Calil Jr. Self-Tapping Screws without Pre-Drilling for Brazilian Reforestation Species. Advanced Materials Research (Online), v. 1025-1026, p. 345-348, 2014.

[5] Calil Neto, C.; ChristoforoA. L.; Ribeiro Filho, S. L. M.; Lahr, F. A. Rocco; Calil Jr, C. Avaliação da resistência ao cisalhamento e à delaminação em madeira laminada colada. 
Ciência Florestal (UFSM. Impresso), v. 24, p. 987, 2014.

[6] Lahr, F. A. Rocco; Christoforo, A. L.; Campos, C. I., Morales, E. A. M.; Barbosa, J. C.; Panzera, T. H. Evaluation of the moisture content in stiffness properties of structural glulam beams. Advanced Materials Research (Online), v. 1088, p. 676-679, 2015.

[7] Christoforo, A. L.; Lahr, F. A. Rocco; Chahud, E; L. Branco, A. M. N.; Battistele, R. A. G.; Valarelli, I. D. Influence of Storage Period of Pieces in Stiffness of Pinus elliottii Glulam Beams. Advanced Materials Research (Online), v. 1025-1026, p. 64-67, 2014.

[8] Segundinho, P. G. A.; Neto, C. Calil; Dias, A. A.; Calil Jr., C.; Christoforo, A. L. Evaluation of Brazilian Reforestation Species in Glulam Beams Before and After Preservative Chemical Treatments. International Journal of Materials Engineering, v. 4, p. 192-195, 2014.

[9] American Institute of Timber Construction - ANSI/AITC A190. American national standard: Structural Glued Laminated Timber. Centennial, Colorado, USA, April, 20,
2007.

[10] Instituto Nacional de Normalizacion - INN. NCh2148. cR2010. Madera: Construcciones en madera. Santiago, Chile, 104 p., 2006.

[11] Brazilian Association of Technical Standard - ABNT NBR 7190. Projeto de estruturas de madeira(Design of timber structures). Rio de Janeiro, 1997.

[12] American National Standard for Wood Products - AITC A190. Structural Glued Laminated Timber. Colorado, USA, 2007.

[13] Canadian Standards Association - CSA 0112.10.Qualification Code for Manufactures of Structural Glued - Laminated Timber. Canadian, 16 p., 2006.

[14] Cavalheiro, R S. Glued laminated timber made with Schizolobium amazonicum Herb. (Paricá): Combination of adhesive, treatment and preservative. Master Dissertation School of Engineering of São Carlos, São Paulo University, São Carlos - SP, Brazil, 2014. 